This article has been accepted for publication by Edinburgh University Press in Cultural History.

Brooker, Will (2016) Alice's evidence: Examining the cultural afterlife of Lewis Carroll in 1932.

Cultural History, 5(1), pp. 1-25. ISSN (print) 2045-290X

http://dx.doi.org/10.3366/cult.2016.0107 


\section{Alice's Evidence: examining the cultural afterlife of Lewis Carroll in 1932}

\section{Abstract}

In the context of recent work on Charles Lutwidge Dodgson/Lewis Carroll, this paper argues that, given the scarcity of new archival information on the author and his life, the cultural 'afterlife' of Carroll and his books, such as Alice in Wonderland, provides a rich alternative avenue for scholarly research. It uses as a case study the 1932 centenary of Lewis Carroll's birth, which, it argues, marks a key transition point in cultural discourses around the author and Alice.

While the Alice books had, by 1932, been adapted to cinema, adopted into advertising and incorporated into a society very different from the 1860 s Britain in which they were first published, they were also subject to conservative notions of authenticity and fidelity to the original. Carroll, who died in 1898, was already considered in terms of literary 'immortality', and his work associated with a nostalgic past, yet he also remained within living memory; the reminiscences of those who had known him when they were children were foregrounded in the press, while 'the real Alice', Mrs Hargreaves, was still alive, and feted as one of the text's cultural curators. Both Carroll and Alice were, meanwhile, subject to new contemporary discourses such as psychoanalysis, and became key to literary tourism and heritage on both a local and national level.

This dynamic, complex point in Carroll's cultural history, studied here through an analysis of primary documents from the period, is presented as an example of the rich potential for detailed scholarship into the afterlife of Alice and its author.

Key words: Lewis Carroll, Alice in Wonderland, tourism, heritage, literature, cultural history, 1930s 


\section{Introduction}

Charles Lutwidge Dodgson, better known as Lewis Carroll, died in 1898, at the age of 65 . His bestknown work, Alice in Wonderland, is still alive, and celebrated its $150^{\text {th }}$ anniversary in 2015 . The five year lead-up to that anniversary saw a number of significant books published on Carroll and his work, including Simon Winchester's The Alice Behind Wonderland, Jan Susina's The Place of Lewis Carroll in Children's Literature, Edward Wakeling's Lewis Carroll: The Man and his Circle, Jenny Woolf's The Mystery of Lewis Carroll and Robert Douglas-Fairhurst's The Story of Alice.

But the problem with the study of Lewis Carroll is that, despite the occasional emergence of new primary material, and the painstaking analysis of what already exists - Wakeling's extensive editing of the diaries and cataloguing of his photography, Woolf's unearthing of his bank account details Charles Dodgson was a private man in life, many of whose belongings and journals were either destroyed, accidentally lost or deliberately censored by his descendants after his death. Each new book on Carroll is therefore obliged to build a major new study based on a minor addition to the archive - a letter, a ledger, a note, a newspaper clipping. The choice for Carrollians is between a sensible reiteration and reconstruction of known facts (epitomised by Wakeling), which can only ever add modestly to our understanding, or a radical but precarious new interpretation (such as Karoline Leach's In the Shadow of the Dreamchild). It seems increasingly unlikely that we will ever gain more concrete documentary evidence about Charles Lutwidge Dodgson himself.

Alice in Wonderland, however, is quite a different case, as is Dodgson's other major creation, 'Lewis Carroll'. Alice and Carroll have enjoyed an incredibly diverse cultural afterlife. Their passage 
throughout the twentieth and twenty-first centuries is, unlike much of Dodgson's life, thoroughly documented - across advertising, journalism, political cartoons, cinema and merchandise - and, unlike Dodgson's life, it remains relatively unexamined. The key twentieth-century biographies of Dodgson - by Florence Becker Lennon (1937), Alexander Taylor (1942), Derek Hudson (1954), Morton Cohen (1995), Michael Bakewell (1996) and Donald Thomas (1997) - added to the contemporary discourse around Carroll and Alice's changing role and reputation without analysing it (or their own contribution to it). Thomas' final chapter, 'Wonderland', is a rare exception, offering a fascinating condensed tour through the book's afterlife, and my own Alice's Adventures engages in a similar project at greater length, focusing largely on the 1990s. Of more recent texts, Jan Susina, after detailing Carroll's establishment of an Alice industry during his lifetime, briefly considers recent editions of the Alice books, and the way they have been adapted to online digital media. DouglasFairhurst offers the fullest recent account of Alice's afterlife, with four concluding chapters and an epilogue on the cultural function of Carroll and his most famous heroine in the twentieth century.

But none of these contributions to Carrollian scholarship attempts a sustained, detailed examination of the cultural discourses around 'Alice' and 'Carroll' at a specific and significant historical moment: rather, they consider what happened to Alice after Dodgson's death as, at best, a postscript, once the evidence about Dodgson is exhausted.

And it seems that - particularly after the publication of Wakeling's book, the result of forty years' research - our available material on Charles Lutwidge Dodgson's life may really be exhausted. But we have ample evidence of Carroll and Alice's afterlife, and in the following I want to suggest the potential of this comparatively unexplored avenue of Carrollian studies: focusing in detail on 
extensive primary documents from key moments in that cultural history, to trace the development of meanings around the author and his most famous work.

\section{The 1932 Centenary}

The 1932 anniversary of Lewis Carroll's birth marks a transitional moment between the sense of Lewis Carroll as a man still remembered as a living individual, albeit the pseudonym of Charles Dodgson, and Lewis Carroll as a symbolic, mythic figure, an icon, a public property who could be invested with various cultural associations: between Lewis Carroll and 'Lewis Carroll'.' In 1898, the year of his death, Carroll was, naturally, mourned as a man who had lived, who was known and remembered by his contemporaries, and survived by his friends and family. By 1965 , the hundredth anniversary of Alice in Wonderland, Carroll was firmly a figure of the distant past, and his life, character and work considered far more freely open to interpretation, adaptation and appropriation. 1932 is a key point of change in these patterns of understanding and discourses around the author.

1932 saw Carroll transitionally situated in relation to time, between living memory and immortality; but the discourses around the centenary also struggled to locate him in space, between a sense of local belonging and a grander position in the English literary pantheon. Towns like Guildford made pragmatic claims for Carroll as a figure of tourist heritage; this specificity coexisted with the view of Carroll as a figure of national, even Imperialist tradition, who proudly extended the reach of English culture across America and the Colonies. 
Carroll was associated with a comforting, nostalgic past, but his work was also seen as prophetically accurate about the sinister nonsense of contemporary politics, even as a harbinger of a darker future. Finally, he was celebrated for his love as children and retained a reputation as the country's 'best-loved uncle', but psychoanalytical approaches were already creeping into popular interpretation, poking after mystery and scandal in Carroll's supposed 'dual personality'. The relationship between this specific literary centenary and national concerns is, of course, highly complex: but we could also see these discourses around Carroll as articulating some of the broader attitudes of the 'hiatus in history' during the inter-war years, this 'interval sandwiched between more dramatic, and more historically significant acts.' As Alison Light describes the period:

Janus-faced, it could simultaneously look backwards and forwards; it could accommodate the past in the new forms of the present; it was a deferral of modernity and yet it also demanded a different sort of conservatism from that which had gone before.

'That dialectic between old and new, between past and present, between holding on and letting go, between conserving and moving on', Light goes on, 'is a constant one and it is differently felt at different places in the culture.' The very definition of 'inter-war', she notes, is a flexible frame. But this particular dialectic, she concludes, 'takes a particularly exciting and intense form between the wars in Britain.' Preparations for the centenary of Lewis Carroll's birth fell, by sheer coincidence, roughly in the middle of that in-between period. ${ }^{\text {iv }}$

An account from 1932 confirms that a significant shift had taken place during even the relatively short, thirty-five year period between Carroll's death and the centenary of his birth. Carroll's fellow 
Victorians, suggested Maud Ffooks at the time, had seen him as both a 'conscientious Clergyman...logical and scientific' and a genius with the 'exceptional power of entering into the thoughts and minds of children, and of writing imaginative tales which should captivate, not only them, but a multitude of seniors with the hearts of children still within them.'

Such he appeared to contemporaries. But after his death in 1898, say from 1900 to 1917, he came to be regarded as, after all, only a Victorian, whose significance began and ended with that age. About fifteen years ago, however, came a change: it began to be felt that there was a timeless element in Dodgson's appreciation of the child-mind. From close contact with the young, and unceasing observation of their still unwarped ideas, he reached the heart of their 'trailings of glory', a secret blend of innocence, wonder and sensibility. ${ }^{v}$

Carroll and his work were, therefore, entering a realm of immortality, while still tied to their cultural moment, which remained firmly within memory. Ffooks is right to argue that Carroll was not regarded as 'only a Victorian' in 1932. However, he was still a Victorian; also a Victorian, among many other things: and this dynamic between competing, sometimes contradictory discourses is what makes the centenary such a key point in his cultural history.

\section{A Classic in Contemporary Culture}

By 1932 Alice had been appropriated by popular culture - advertising, political satire and cinema and allowed to circulate freely, often without the anchor of her author and original illustrator. ${ }^{\text {vi }}$ Alice 
had moved into new media, been embraced by new artistic movements and lent herself to interpretations far removed from Lewis Carroll's historical context. And yet there is a tension evident across the centenary celebrations; although Alice was no longer considered tied to 1865 or even to 1898, and had gained modern associations, still there was clearly a need to root her in authenticity and authorship, both in terms of Carroll's writing and Tenniel's illustrations.

Despite the many other artists who had worked on Alice by the 1930s - including Willy Pogany's very contemporary 'flapper-girl' Alice of 1929 - the flyers, brochures and posters advertising centenary events invariably use Tenniel's images, or a redrawn approximation of them. 'Refreshing as it is to see new interpretations of such well-known beings as the characters of "Alice",' wrote one contemporary critic, commenting on designs for a new ballet, 'I am inclined to think that we shall never quite get away from Tenniel. Miss LindsleySims does not go far from him, but even a compromise is hard to accept.'

Figure 1. Tenniel illustrations on 1932 centenary materials.

(Source: Surrey History Centre, Woking)

A programme for the Duke of York Theatre's centenary production of Alice in Wonderland epitomises this dynamic between the lure of the contemporary and the continued need to guarantee fidelity and authenticity to the original: a note in bold confirms that the producer has made every effort to keep as faithfully as possible to the spirit of Lewis Carroll's "Wonderland". No

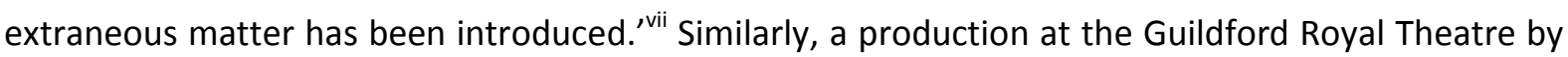


the Cockyolly Company of Amateur Players stresses that 'every care is being taken to keep as closely as possible to the book, and Lewis Carroll's language is used throughout... ${ }^{\text {viii }}$ while a letter inviting the Misses Dodgsons, Carroll's nieces Violet and Menella, to a production at the Little Theatre in London promises 'I think you will be pleased with one thing, and that is that there is nothing in the play that is not Carroll..$^{\text {ix }}$

Inevitably, Alice occupies a 1930s popular context during the centenary, alongside promotions for modern products and entirely unrelated entertainments. At the Birmingham Repertory Theatre, a musical of Alice was succeeded by a broadcast of The Happy Hangman: A Grotesque in One Act; ${ }^{\mathrm{x}}$ at the St James' Theatre, a fundraising ballet of Through the Looking-Glass was billed as an 'All-Star Matinee' and accompanied by 'boys' boxing matches' and 'the street scene from The Gay Adventure'. ${ }^{\mathrm{x}}$ The Daily Memo reporter who attended the event was very taken by the 'bevy of pretty girls who danced on the stage' dressed as Cheshire Cats and White Rabbits; ${ }^{\text {xii }}$ while another reporter devoted almost the entire column not to Alice in Wonderland but to the show's principal ballerina, Miss Alice Alanova. ${ }^{\text {xii }}$ Lewis Carroll, ostensibly the reason for the 'all-star programme', was mentioned only in the final sentence.

A Varsity Ball, also to raise money for the Lewis Carroll Memorial Fund, was similarly up-to-date, offering a 'Hot Dog' supper, Beer and Running Buffet. ${ }^{\text {xiv }}$ For those who could not make it to the theatre, broadcasting technology also brought Alice into the home: a 'special feature programme from the North Regional transmitter', on 27 January 1932, combined characters from both Alice books, the Snark and Phantasmagoria. ${ }^{x v}$ 
These glimpses of a brasher and more careless contemporary culture, already influenced by Hollywood, may sit strangely next to Carroll and Tenniel's quintessentially English and distinctly Victorian heroine. However, despite these modern distractions, a stern sense of authenticity and tradition remained in place. 'All the "Alice" illustrations in this pamphlet are reproduced by permission of the Lewis Carroll Executors and Messrs. Macmillan and $\mathrm{Co}^{\prime}$, confirms one document, ${ }^{\text {xvi }}$ while another includes an advertisement from the publisher, reminding playgoers not only to read the two Alice books, but that 'only the Macmillan Editions of "Alice" have the famous Tenniel illustrations. ${ }^{\text {xvii }}$ The brochures' photographs of contemporary actresses in stage productions are also carefully composed and framed after the Tenniel originals. Even the All-Star Matinee with the pretty girls in rabbit heads carried the stamp of literary authority through its auction of Alice first editions, autographed by 'Mrs Caryll [sic] Hargreaves...Alice herself', who was present at the performance. xviii

\section{Curators of Carroll}

William M. Johnston notes that 'the agencies that sponsor commemorations derive from bourgeois adaptation of aristocratic ways'; he identifies, in twentieth-century anniversaries, a secular, 'pseudocourtly' system of patronage that derives 'from initiatives and eighteenth- and nineteenthcentury rulers. Often their successors exude an Old Regime aura... in their modes of operation. ${ }^{\text {xix }} \mathrm{A}$ recurring list of names served as, in Johnston's phrase, the 'cultural managers' of Carroll in 1932, guaranteeing the authority and authenticity of Alice events. We have seen the importance of the Macmillan publishing company as the holders of Tenniel's original illustrations, the recurring use of Tenniel's images themselves, and of course the name "Lewis Carroll" as a form of branding. ${ }^{\mathrm{xx}}$ Local celebrations, such as the Cockyolly Company's performance at Guildford, were invariably attended by the regional Mayor and Mayoress, and the presence of HRH the Duchess of York was noted at the 
All-Star Matinee. However, other forms of cultural status also carried weight. The Lewis Carroll Centenary exhibition was hosted by established booksellers John and Edward Bumpus, and organised by former Bodleian librarian Falconer Madan and barrister Sidney H. Williams, co-authors of a new Handbook of the Literature of the Rev. CL Dodgson (Lewis Carroll).

The campaign to establish a Lewis Carroll Ward for Children at St Mary's Hospital was initially established, with the approval of The Duchess of York, by senior political statesmen Stanley Baldwin and Ramsay McDonald in company with publisher Frederick Macmillan and contemporary children's authors A. A. Milne, J. M. Barrie - celebrated, of course, for Winnie-the-Pooh and Peter Pan - and Walter De La Mare - though the idea seems originally to have been suggested by another author, Langford Reed. 'May I, as the author of the forthcoming biography of Lewis Carroll, compiled with the authority of the Dodgson family, suggest that such a ward be inaugurated, with the proviso that, if the idea be taken up, a member of that family be asked to select the hospital?' ${ }^{\prime x i}$ Reed's boast of his own credentials tends to confirm Johnston's theory of pseudo-courtly attitudes and Old Regime conventions.

At the top of this hierarchy, then, above even former Prime Ministers and royalty, were those directly linked to the original Alice story, its author and its subject, through blood and marriage. Carroll's descendants were respectfully invited to attend events, as we saw from the above note to Violet and Menella Dodgson, and were cited to lend approval to centenary proposals. Other members of the family were also consulted and regularly named as figures of authority - 'Major Dodgson... is favourable to the scheme', reported Madan and Williams of the Centenary Exhibition ${ }^{\text {xxi }}$ - while Violet Dodgson herself was a special guest at St John the Divine's Centenary Fair in Kennington. ${ }^{\text {xiii }}$ Notably, though Miss Dodgson only appeared for one day at the fair, and was given 
equal billing with actress Irene Vanbrugh, while Alice Hargeaves, billed as the 'original "Alice"', was prominently listed even in her absence.

Alice Hargreaves was also present at the Lewis Carroll Centenary Exhibition at Bumpus in London, organised by Madan and Williams: one reporter celebrates her, tellingly, as 'a definitely authentic link...the original "Alice" of the Halcyon River expedition. ${ }^{\text {'xxiv }}$ Indeed, Madan and Williams express a genuinely pleasurable surprise, apparently shared by many commentators, that Alice was still alive: a Daily Mirror headline exclaims 'I Saw Alice, of "Alice in Wonderland" - She Is Still With Us'. ${ }^{x v}$ Yet the centenary placed great responsibility on a woman of 80 , still serving as a figurehead and expected to stand for a fictional character. As we see from the way she was consistently described, Mrs Hargreaves was asked to become something more than simply a private, elderly individual: she was also the 'original "Alice", still belonging to the book, to 'Lewis Carroll', and to the public. No wonder she confessed to her son that she was 'tired of being Alice in Wonderland. Does it sound ungrateful? It is - only I do get tired!'; ;xvi and no wonder she wrote to Miss Dodgson in July that she would be happy to meet her and shake her hand at the theatre, but that 'November seems a long way off to promise anything. ${ }^{\text {'xvii }}$

It is unsurprising also, perhaps, that members of the Dodgson family felt their own role and family name had been marginalised by the 'original Alice'. F. Menella Dodgson wrote to her brother Wilfrid on June 30, 1932 that while many of their cousins were at the Opening [of the London Exhibition], 'the Dodgson name, except as referring to Uncle Charles himself, was neither heard, nor read of, nor was, as far as the public was concerned, one seen. [...] as a matter of fact, according to the cuttings we have got this morning, it was Mrs Hargreaves who got by far the largest share of the honour and glory! $!^{\text {xxviii }}$ 


\section{In Living Memory}

So the dynamic around Alice at this particular historical moment reveals a tension between the contemporary and the classic: between Alice as an entertainment with hot dogs, beer and boxing, and Alice as a canonical text with the high-status cultural associations of first editions, authentic illustrations and original publishers. Lewis Carroll was caught in a similar dynamic; he was at once seen as distant, a Victorian author or, even more remotely, as an immortal, timeless figure of literature, and conversely, as a person who was still remembered, albeit by an elderly minority.

For a brief time, respondents in their seventies and eighties - often women - found themselves in a uniquely privileged position; valued for their stories of Carroll, featured on the letters pages of British newspapers, interviewed for articles and, in the case of Mr Francis, the 91 year-old verger of Christ Church, leading tours of the Londoners' Circle, a group of aficionados, around Carroll's former home. ${ }^{x x i x}$ These specific reminiscences of Lewis Carroll, again, can be seen as part of a wider nostalgic discourse. David Lowenthal notes that the 1920s and 30s saw 'quaint' and 'old-fashioned' become terms of praise: 'to be up-to-date now meant to look as old as possible.'

Prime Minister Stanley Baldwin joined Poet Laureate John Masefield in shedding tears over the past. 'Our Bill', BBC's immensely popular 1930s programme, extolled the ancient traditions, the old churches, the wayside inns of the English countryside where one could 'step aside in some small pool of history, to be lapped awhile in the healing peace of a rich, still-living past." ${ }^{x x x}$ 
To pick just a few examples, Rose L. Wood, in The Times in February 1932, recalled an occasion when Carroll, showing her the proofs of Through the Looking-Glass, asked what the Red Queen should become at the end of the story. 'She looks so cross, please turn her into the Black Kitten,' the 12 year-old Rose suggested, and Carroll supposedly approved: 'That will do splendidly.' ${ }^{\text {xxxi }}$ Another correspondent, named only G.B.H., describes her most 'cherished childhood memories' of Carroll, 'that unique friend of little girls', when she was six years old and on a visit to Eastbourne. 'I recollect him best as someone who really understood my feelings when grown ups told me that I could not, or must not, do certain things. ${ }^{\text {xxxii }}$ And a group of 'little girls of Guildford, now grown older' recalled, in the Surrey Advertiser, a 'happy railway journey when Lewis Carroll...lent them his copy of Jules Verne's book, "Ten Thousand Leagues Under the Sea”[sic], to pass the time. ${ }^{\prime x x i i i}$ These stories, based on half-memories of the past and the books, woven together with wishful thinking, almost seem like fond dreams themselves.

At a point where reports of Carroll's life were almost entirely reliant on the details of his nephew Stuart Collingwood's biography from 1898, supplemented with Victorian gossip, to the extent that many newspaper articles repeated the same dubious anecdotes - he made friends with snails, toads and worms while growing up in Daresbury, he sent Queen Victoria his works on mathematics when she asked for more by the author of Alice - any new information was welcomed and presented as reliable truth, even when it seemed implausible - the product of either a flawed memory or an overeager desire to provide new stories about the storyteller. Already by 1932, wild rumours about Carroll's romantic secrets had begun to circulate: Miss Amy Dovaston, of Ealing, told the Daily Mail that Carroll, who had tutored her brother at Oxford, had been deeply in love with Violet Liddell, 'who had died at the age of 18 or $19 . .$. of a broken heart.' Dean Liddell, her father, supposedly forbade marriage due to Carroll's limited finances and prospects. 
From that moment Violet pined away, and the tragic end of his romance darkened Carroll's whole life. It was really in memory of his lost love that Carroll wrote his wonderful stories for her sister. ${ }^{\text {xxiv }}$

In fact, Violet Liddell was born in 1864 , two years after the Alice story was first told, and died in 1927, so this version of events is unlikely; but as lurid theories about Carroll have demonstrated ever since, dull historical facts cannot stop the publication of a vivid story.

\section{National Treasure, Local Hero}

Through these enhanced, exaggerated, unreliable and sometimes simply untrue stories, Carroll even as a remembered individual - was constructed as a larger-than-life figure, a set of received ideas and anecdotes. At the same time, he and his work were already being celebrated as a timeless part of literary heritage, in a discourse that lifted him from the realm of living memory, however unreliable, and into the sphere of myth. Carroll's public persona, as perceived through his books, his letters and anecdotes circulating around him, positioned him as an English cultural treasure, in the terms suggested by William Johnston. 'Whereas America's civil religion celebrates ideals of toleration, progress, and social mobility, Europe's cult of luminaries exalts rather different ones: creativity, versatility, and genius...individual vision' and 'one-of-a-kind' achievement. ${ }^{\mathrm{xxv}}$

The word 'immortal' appears frequently in newspaper reports of the centenary: a prime example is the speech given by the Marquess of Crewe at the unveiling of a plaque in Guildford, celebrating 
Carroll's previous residence at The Chestnuts. Lord Crewe placed Lewis Carroll, without hesitation, 'among the select band of immortal writers of our English language', and the Alice books alongside Pilgrim's Progress, Gulliver's Travels and Robinson Crusoe. .xxvi $^{\text {xin }}$

Figure 2. Lord Crewe admires the plaque at 'The Chestnuts', Guildford.

(Source: The Surrey Times)

Another newspaper correspondent pairs him with Edward Lear as 'masters of nonsense', ${ }^{\text {xxvii }}$ while a further article, arguing for a Guildford Commemoration Hall that never came to pass, admits that Carroll is not yet 'ranged alongside Shakespeare' but argues that 'in the world of letters...he won a lofty and lasting niche for himself' and deserves a public hall equivalent to the new Shakespeare Memorial Theatre at Stratford-Upon-Avon. ${ }^{\text {xxviii }}$

As an increasingly treasured part of literary history and a valuable cultural asset, Carroll was, as the above article suggests, becoming co-opted as part of what we would now call literary tourism: a 'new desire to visit the graves, the birthplaces and the carefully preserved homes of dead poets and men of letters' that, as Nicola J Watson points out, began in the eighteenth century and had reached its peak by the 1930 s. $^{\text {xxix }}$

Carroll's reputation now secured him in a national pantheon, and assessments of his work in the centenary year stressed both his Englishness and his worldwide fame, celebrating his success in America and the Colonies. ${ }^{\mathrm{xl}}$ At the same time, though, several locations around England also sought to claim him as their own, in a tension hinted at by William Johnston's account of British anniversary 
customs: 'the cultural figures being celebrated each year...become carriers of national and regional heritage during that year..$^{\prime x i}$

A report on Lord Crewe's unveiling of the Guildford plaque neatly captures this dynamic in its subheading, 'Local and Empire Occasion.' The Mayor, opening the event, proudly stressed the global context: 'It was...fitting that while they were celebrating a local occasion and an Empire occasion together, that the ceremony should take place on Empire Day and by such a well-known servant of Empire. ${ }^{\text {xlii }}$ His Lordship's response, in turn, elegantly straddled the local and the national, acknowledging that the unveiling of the plaque was 'a notable occasion for Guildford as it would be for any English town that cherished and valued the cheerful traditions of their national life'.

It is notable though that Lord Crewe, who - as former Secretary of State for India, and more recently Secretary of State for War - had no doubt seen enough of Empire and militaristic bombast, reframes the occasion away from the 'dynamic and missionary view' espoused by the Mayor's introduction, and suggests a more modest scope, in tune with what Light describes as a inter-war 'Englishness at once less imperial and more inward-looking, more domestic and more private,' a national identity that quietly celebrated 'civilian virtues and pleasures' ${ }^{\text {xliii }}$ Even in this brief exchange, we can discern a sense of subtle tension in the way England presented itself publicly in 1932 - a dynamic between expansionist rhetoric and quieter conservatism ${ }^{\text {xliv }}$ - focused and foregrounded here through the celebration of a literary figure who was born a hundred years before, and who died at the end of the previous century.

The campaign to mount a plaque outside The Chestnuts began when the Mayor placed a modest wreath on Carroll's grave, with the inscription 'a token of Guildford's pride in remembrance'. ${ }^{x / v}$ 
Carroll's link with the town was, according to one article from the time, a relatively recent discovery - 'a connection known to comparatively few until his death twenty-five [sic] years ago.' At this point, the date of his sisters taking residence in Guildford, and Carroll's lease of The Chestnuts, was still unknown. ${ }^{\text {xlvi }}$ Relying on Stuart Collingwood's biography, this article notes, 'does not tell us much about "Lewis Carroll's" life at Guildford,' so the reporter is obliged to imagine it as 'probably a busy though quiet one, for Mr Dodgson hated to waste time, and he had always plenty of work on hand.' Another article even boldly claims that Carroll 'spun the fanciful account of Alice's fascinating adventures' not in the environs of Oxford, while sitting in the gardens of The Chestnuts with 'Alice and her companions. ${ }^{\text {’lvii }}$

As Watson notes, the presence of the author's literal remains carried a great deal of cultural weight in heritage tourism - she terms this impulse to commune with the dead 'necro-tourism' - ${ }^{\text {xlvii }}$ and a contemporary report shows that despite the lack of concrete information, the local press recognised pragmatic reasons to confirm and foreground Guildford's Carrollian association, even if the word 'tourism' is elided here, euphemistically, by 'pilgrims'.

... the Corporation of Guildford have undertaken to be responsible for keeping in order for all time a grave which already attracts pilgrims from distant places, and is likely to attract them in greater numbers in the future. Guildford has, therefore, more than passing interest in the centenary of one whose fame has travelled to the ends of the earth. ${ }^{x \text { lix }}$

The plaque was duly manufactured, paid for and mounted- the cost, over $f 70$, funded largely by the Alice performances of the Cockyolly Company - and as Lord Crewe presided over the ceremony 
outside 'the house where [Carroll] spent many holidays with his sisters, and where he died';' a report acknowledged, perhaps with false humility, that 'Guildford has only done its duty' by 'erecting the plaque in commemoration of one of its most renowned citizens. ${ }^{\text {li }}$

Ironically, Lord Crewe's speech, ostensibly confirming the author's association with Guildford, reminded listeners that Carroll was, 'as they knew, not a son of Guildford, not a Surrey man, but came from the northern midlands. His whole active life was spent at Oxford. ${ }^{\text {lii }}$ Local newspapers tried to play down these inconvenient historical facts: another piece in the Surrey and County Times, stressing 'Guildford Associations' in the title, admits that Carroll's birthplace was in the North, but informs its readers with condescension that Daresbury is 'a little village several miles from Warrington'.lii Watson observes that the phenomenon of pilgrimage to an author's birthplace is based on an even more tenuous sense of communion than the 'necro-tourism' that draws visitors to a grave, and requires 'a substantial effort of the collective imagination'; perhaps for this reason, Daresbury took far longer than Guildford to capitalise on its connection with Carroll. ${ }^{\text {liv }}$

Oxford, inevitably, made its own claims in 1932: the local press reminded readers that 'Lewis Carroll spent much of his life in Oxford and Christ Church,' and the Dean of that college offered a group of literary pilgrims from London a rare visit to Carroll's rooms and an exhibition of his documents in the library, curated by Falconer Madan. ${ }^{\text {Iv }}$ It is worth noting that, at this point, Oxford was not apparently capitalising on the connections between the town and the text itself. The town's tourist industry now incorporates the treacle-well at Binsey, the riverbank near Godstow, the 'Sheep Shop' near Christ Church, and various design oddities such as the Magdalen College gargoyles that supposedly inspired the Red Queen, in a flattening of fact and fiction: 'testimony to a still vital realist desire to locate text within place, however fantastic the book. , lvi $^{\text {in }}$ 
Figure 3. The Londoners' Circle.

\section{(Source: Surrey History Centre, Woking)}

It may have been from a sense of emerging rivalry between heritage location, that the Daily Express reported that the grave at 'Guildford (Surrey)... lies lonely and neglected. No hand tends its narrow plot... The grass of the plot is thin and sparse; the border of the tomb green with mould and age. 'lvii The Guildford press replied swiftly and indignantly.

His grave is not, as has been stated in two or three London publications this week, neglected. It is trim and tidy, and well-tended. The green turf covers it save at the foot, where forget-me-nots and bulbs have been planted. And its future care is assured by the decision of the Town Council to maintain it in perpetuity. ${ }^{\text {Ivii }}$

In the proposal for a never-built Commemoration Hall at Guildford, the discourse of heritage tourism reaches its most explicit and urgent form. The author stresses the need to add 'something which would, for all time, more closely link and identify the name of Lewis Carroll with the town of Guildford', and the need to benefit Guildford itself is barely disguised: the town 'requires a public hall more thoroughly in keeping with its ancient state, its prestige and importance as the county town of Surrey, and its civic dignity'. A call for funding would stretch out to 'every country where "Alice in Wonderland" is read - to America, France, Germany, Italy, and the British Dominions beyond the seas. ${ }^{\text {lix }}$ 
Once more, we can see here the ongoing dynamic between Carroll as locally-specific and worldfamous; between Carroll the man, former resident of a particular place, and Carroll the myth, a timeless figure translated into many languages. Here, the latter is proposed in service of the former, as Carroll's global celebrity is appealed to in order to fund a Guildford landmark. That the proposal failed, and that Guildford - barring two Alice statues from 1984 and 1990 - still has no more significant memorial to Carroll than the tombstone and the Chestnuts, suggests the scale of the challenge. ${ }^{\mid x}$

Alice herself was not immune to this form of tourism: one headline exclaimed 'Alice in Wonderland Was A Hampshire Lady...NOW LIVES IN KENT' ${ }^{\prime x i}$ and an article entitled 'Lewis Carroll and Hull' went even further, announcing that Lewis Carroll's grandfather 'lived at Hull in 1805'. Ixii These claims, sometimes stretched ludicrously thin, themselves suggest the increasing importance of literary tourism and heritage at the time.

\section{Innocence and Suspicion}

Carroll's relationship with history was, then, at a fascinating point of balance in 1932 . On one hand, he was still recoverable, albeit precariously and unreliably, within living memory. On another, he was becoming sanctified and preserved as a figure outside and beyond time, part of the pantheon of immortal English writers. Finally, however, he was remembered as a distinctly Victorian writer, the contemporary of Ruskin, the Rossettis, Millais, Thackeray and Tennyson, ${ }^{1 \text { xii }}$ and the product of a period still recent but increasingly distant, and recalled ambivalently: sometimes as dry and formal, ${ }^{\text {lxiv }}$ but also as an era poignantly lost, associated with comforting innocence. 
The Manchester Guardian remarks wryly that what seemed nonsense in Carroll's day now, in the interwar years, seems sadly to have come true. 'The present state of the world', the reporter observes, is 'more like Wonderland than ever...'

It is now evident to the dullest intelligence that the Treaty of Versailles was written in looking-glass writing...and it must look more confusing than ever to statesmen who are still trying to read it while standing on their heads, like Bill the Lizard in the jury-box. As a matter of fact it is not 'Alice' but some of the other books which might have been specially drafted with a prophetic eye on to-day. What could be more characteristic of our own times than the cry of the crazy political demonstrators who introduce the dream-world of 'Sylvie and Bruno'? 'Less Bread, More Taxes!' may have seemed a phantasy to the eminent but secluded Victorian, but to-day real Cabinets agree to differ on it as a guiding principle in political affairs. Again, our fathers and grandfathers confessed their inability to fathom the exact significance of 'The Hunting of the Snark'. What if it should turn out to be the quest of Reparations, or the fell Boojum that will ultimately engulf us all? $?^{\mid x v}$

Yet while Alice prompted a prophetic, almost apocalyptic looking-forward from 1932, it had also played a comforting role during the previous war, and those associations were still remembered. 'The author of the play "Journey's End"', writes one journalist in the Church Times, referring to R. C. Sherriff's work of 1928, 'was never more faithful to reality than when he made Osborne, the cultured schoolmaster, read with delight his little, leather-bound copy of Alice's Adventures in Wonderland in a front-line dug-out'. ${ }^{\text {lxi }}$ 
Another Church Times writer pays similar tribute, describing how he can identify the Alice books by their familiar feel. 'Some years ago', he recalls,

when a dispute broke out on the mainland, I steamed across the English Channel, like most others of my peers, in the service of King and Country. There was not much room for books in our baggage... what should I choose, of all the books in the world?

My choice was made without much difficulty. I stuffed into my kitbag Bradshaw's Railways Guide and "Alice in Wonderland." I never regretted my choice. Bradshaw became the most popular work in our mess. We worked out cross-country journeys, going on imaginary visits to country houses that seemed to belong to a dream-world, half forgotten. As for Alice, was there one of us to whom she was not a very part of England, of home and childhood?'

'I was brought up on Alice,' he confides. 'It was a domestic classic. Ixvii To echo Alison Light, it is hard not to wonder, reading these reflections on Carroll in what now seems a period poised between conflicts:

How much people felt what we now know to be their future pressing upon them, how far they lived in expectation or in suspense, reading the entrails of the present signs of what was to come, and how far they were moved by the forms of the past, aware of it as loss, as comfort, or as an invisible force in their lives... ${ }^{\text {xviii }}$

Carroll was still celebrated in 1932 for his love of children, and the fundraising campaign for a 'Lewis Carroll Ward' for children was seen as 'the most appropriate method of establishing a permanent 
memorial to his name, other than that represented by his works. Ixix $A$ Daily Express article characteristically describes Carroll as 'Man Who Held Key To Children's Hearts': he 'was and is the world's best-loved uncle. ${ }^{1 \times x}$ One of the centenary articles in the Surrey Advertiser describes the 'real Lewis Carroll' without apology or concern as a 'lover of children', 'particularly girls'. ${ }^{\mid x \times i}$

The involvement of children in the centenary celebrations is regularly mentioned, as if to confirm Carroll's continuing importance to and popularity among young readers. 'Between 200 and 300 children, in addition to a large number of adults', attended a service in the author's honour at Liverpool Cathedral, ${ }^{\mid \times x i i}$ while the provision of the Guildford plaque 'was appropriately due to the efforts of children...the greater part of the cost was met from the proceeds of the successful performances of the two Alice stories given by the Cockyolly Company of children last year. ${ }^{, \mid x x i i i}$ The Mayor confirmed that 'the children did the work, and they took a joy in doing it, and the plaque was really the mark of the grateful remembrance of the children of Guildford. ${ }^{\text {, lxiv }}$

Madan and Williams describe Carroll's books as 'still the delight of every child, and of every one with the heart of a child'; ${ }^{\prime \mid x x v}$ certainly, the children of 1932 dutifully played their part, but more significant yet is the role of Alice for adults, who clearly remembered its importance to their own childhood, and were reassured in seeing it passed down to the next generation. The Appeal Leaflet for the Lewis Carroll Memorial Ward suggested the adult debt to Alice:

During more than half a century Alice has been helping grown-up people to make the difficult journey back to the wisdom of childhood... She has proved so lively and gentle a guide that there are, certainly, in the world to-day millions of men and women who 
wish to thank her. How are they to do it? ? $^{\mid x v i}$

The leaflet was quick to explain: ' $₫ 5$ will purchase the necessary Bedding for a Cot.'

Whether or not Alice was still genuinely popular with young readers - the Yorkshire Evening Post reported that Lewis Carroll was 'read more by grown-ups than children in these days'lxxvii - this wholehearted, unproblematic celebration of Carroll's 'love for children' contrasts dramatically with the discourses of the 1990s and 2000s, during which time contemporary fears of paedophilia were projected backwards onto Carroll's behaviour and attitudes - within a very different Victorian context - and his reputation became overshadowed by often vicious rumour. One newspaper article from 2000 proposed that he was 'indisputably a paedophile', another, from the following year, described him as the 'disgusting Lewis Carroll', whose 'paedophile longings... are made absolutely clear' by his photography. ${ }^{\text {Ixviii }}$

This reading began very shortly after the centenary, and ironically developed in part from a desire to reconstruct and recover the nostalgic past: Lowenthal notes that 'faith in memory animated Freudian psychology', while 1930s neuro-surgery seemed to confirm the existence of 'a key to the

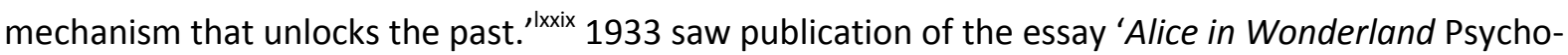
Analysed', which interpreted the rabbit-hole, the locks and keys and little doors as sexual symbols. The author, A. M. E. Goldschmidt, may have intended this piece as a parody, but it was followed in 1938 by an entirely serious article by Paul Schilder, who viewed Wonderland as a world 'of cruelty, destruction and annihilation', and remarked that 'the promiscuity in Carroll's relationship to children is interesting. He seemingly tried to get in contact with a very great number of children and to "seduce" them in this way. ${ }^{\prime 1 \times x}$ William Empson's near-contemporary essay of 1935, 'Alice in 
Wonderland: The Child As Swain', acknowledges the psychoanalytic potential of Carroll's work in a more measured response: 'the books are so frankly about growing up that there is no great discovery in translating them into Freudian terms'. Ixxxi In prefiguring and informing later studies such as Martin Gardner's Annotated Alice, first published in 1960, Empson makes a significant contribution to the literary analysis of Carroll's work, although his considered approach proved to be less broadly influential than the hysterical claims of Goldschmidt and Schilder.

In 1932, then, we can see the start of an interpretative strand that probed for hidden meanings beneath the surface of both Alice and Carroll. We have noted that, in the absence of new information about the author, journalism had already begun to repeat rumours and incorporate unlikely stories from those who claimed to remember him. The apparent split between the private C. L. Dodgson and the pseudonymous Lewis Carroll added to this sense of mystery, and prompted journalistic speculation about 'the clever but modest Oxford don who combined strangely an equal talent for mathematics and the writing of children stories'. ${ }^{\prime} \times x x i$ Another article, even more strikingly, compares the author to 'Jekyll and Hyde', and proposes that 'Dodgson's almost dual personality - his devotion to abstruse mathematical study and his power to shut all this out and to become the ingenious weaver of delightful nonsense - will always fascinate psychologists. ${ }^{, \mid x x x i i i}$

For better or worse, the prediction was accurate. This obsession with the enigma of Lewis Carroll led to Florence Becker Lennon's biography of 1947, with its bold announcement that 'people have wondered what he did with his love-life... now it can be told'; it led to Alexander Taylor's The White Knight, in 1952, which claimed that Alice Liddell was Carroll's 'lost love, the withered rose in his filing-cabinet, the little ghost that was to come crying in the night'. ${ }^{\text {Ixxiv }}$ It led, in turn, to Hugh Haughton's description, in a new edition of Alice from 1998, of Carroll's 'mysterious paedophile 
sexuality' and 'obsessive fascination with girls before puberty', ${ }^{1 \times x \times}$ and by extension, to the various adaptations that identify darker meanings in the Alice books, such as the graphic novels Arkham Asylum (1989) and Haunted Knight (1996), American McGee's two fantasy-horror Alice video games of 2000 and 2011, films such as Jan Švankmajer's Alice (1988) and Dennis Potter's 1985 film Dreamchild, itself set at the centenary in 1932.

In studying the 1932 centenary we witness the point where, as Carroll's birth was commemorated, the last living links with him as an individual were fading. Alice Hargreaves travelled to the US just before her $80^{\text {th }}$ birthday, May $4^{\text {th }} 1932$, was feted at Columbia University and died in 1934 . By the start of the Second World War, very few people would be left alive who remembered Lewis Carroll, and he drifted further loose into cultural mythology, the subject of increasingly unstable rumours, speculation and interpretation.

The concrete reality of Carroll as a person - as Charles Lutwidge Dodgson, a man who was born in 1832 and died in 1898 - was reduced, even by 1932, to a set of stories, a frustratingly sparse collection of primary evidence, and a modest archive of unreliable recorded memories from those who had once known him and had since passed on. Carroll, for better or worse, became part of the popular consciousness, part of cultural myth. This once very private man, having travelled through a curious period of transition, emerged at the end of the English inter-war years as public property.

1932 was, I have argued, an important transition point in the discourses around Alice and Carroll. I have demonstrated that those discourses can be reconstructed in depth and detail through the available archival materials, and related to broader discourses around, for instance, nation, nostalgia, literature and heritage. My study here has focused largely on Guildford and Surrey, 
Carroll's home in his later years and the site of his grave - far more work could be done on the meanings of Alice and its author in early-Thirties Oxford, around his birthplace in Daresbury, and in New York, where Alice Hargreaves received her honorary doctorate from Columbia. We have seen the extent to which Alice's Victorian Englishness had become mingled by 1932 with modern American culture; no major Carrollian study has yet examined the evolution of Alice in United States cinema and advertising, or traced the contemporary Japanese fandom and fascination with Alice to its historical source.

1932 was significant. But there were many other transition points in Alice's afterlife. The project I have begun here could readily be applied to the 1965 centenary of Wonderland, in the context of the Jefferson Airplane's 'White Rabbit' and the countercultural appropriation of Disney's psychedelic film; to the $150^{\text {th }}$ anniversary of Carroll's birth in 1982, at the time of the Falklands War, amid Thatcherite discourses of nation and a nostalgic tradition of British heritage cinema; and to the 1998 centenary of his death, which sought to celebrate a man who was, at the time, popularly imagined to have been a paedophile.

Rather than continue to reshuffle the limited evidence we have about Charles Lutwidge Dodgson, and produce interpretations that perhaps reveal more about our own cultural concerns than they do about the man himself, I propose that further studies should take up the broader challenge of engaging with what twentieth and twenty-first century culture did with Lewis Carroll and his work, and what that process says about us. 
'In film theory, Peter Wollen uses 'Hawks' and 'Hitchcock' to distinguish the directors Howard Hawks and Alfred Hitchcock from the textual 'structures named after them'. Of course, the fact that Lewis Carroll was already the construction of Charles Dodgson complicates the dynamic further, in ways that it is only possible to suggest here. See Peter Wollen, Signs and Meaning in the Cinema (Bloomington: Indiana University Press, 1972), p.168

ii Again, to an extent Lewis Carroll was already an iconic celebrity figure in 1898, but there remains a distinction between this historical point, when the man himself was known personally by many of his contemporaries, and 1998, when he could only be retrieved and reconstructed through sparse archival texts.

iii Alison Light, Forever England: Femininity, Literature and Conservatism Between The Wars (London: Routledge, 1991), pp.9-10. Note that Light is describing here a 'masculine public rhetoric' of the inter-war years, which her book seeks to interrogate and challenge.

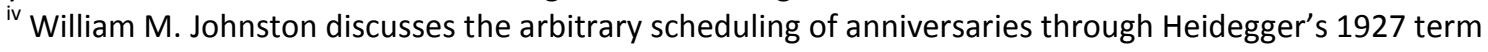
'thrownness' (Geworfenheit), which expresses the idea that 'each of us is thrown into the world at a time and in a place not of our choosing, indeed not of anyone's choosing.' Celebrations: The Cult of Anniversaries in Europe and the United States Today (London: Transaction Publishers, 1991), p.28

${ }^{\vee}$ Maud Ffooks, Catalogue from the Lewis Carroll Centenary 1932, DFC/J/4

${ }^{v i}$ See Will Brooker, Alice's Adventures: Lewis Carroll in Popular Culture (London: Continuum, 2003), pp.77-82, and Donald Thomas, Lewis Carroll: A Portrait with Background (London: John Murray, 1996), pp.356-260

vii Programme for Duke of York's Theatre production of Alice in Wonderland, held in Dodgson Family Collection DFC F $6 / 1 / 4$, Surrey History Centre, Woking

viii Programme for Lewis Carroll Centenary Guildford Celebration, DFC F 5/15e

${ }^{\text {ix }}$ Letter from Nancy Price to Miss Dodgson, DFC F 6/1/4

x Programme for the Repertory Theatre, Birmingham, Christmas 1932, DFC F 6/3

${ }^{x i}$ Anon, 'A Lewis Carroll Matinee', The Times (4 July 1932)

xii Anon, 'Fun of being a White Rabbit', Daily Mirror (13 July, 1932)

xiii Anon, 'Miss Alice Alanova: Graceful Dancing at Carroll Matinee' (newspaper source unknown, 7 July 1932)

${ }^{x i v}$ Preliminary Notice for a Varsity Ball at the Dorchester, DFC F 4/7

${ }^{x v}$ Anon, Oxford Times (15 January 1932)

xvi Programme for Lewis Carroll Centenary Guildford Celebration.

xvii Programme for Duke of York's Theatre production of Alice in Wonderland.

xviii Anon, 'Fun of being a White Rabbit'.

xix Johnston, Celebrations, pp.86-87

${ }^{x x}$ What Foucault would call the 'author-function': see Michel Foucault, Language, Counter-Memory, Practice, (Oxford: Blackwell, 1977)

x×i Langford Reed, 'Lewis Carroll Centenary', Sunday Times (21 February 1932)

xxii Major Charles Hassard Wilfred Dodgson, the son of Wilfred Dodgson, and Lewis Carroll's nephew, referred to by his sister Menella as Wilfred, below.

xxiii Pamphlet for Centenary Fair at St John the Divine, Kennington, DFC F 7/5a

xxiv Anon, 'Commemorating Alice', Yorkshire Post (27 June 1932)

${ }^{x \times v}$ Anon ('Uncle Dick'), 'Uncle Dick's Letter', Daily Mirror (27 January 1932)

xxvi Quoted in Morton Cohen, Lewis Carroll: A Biography, London: Macmillan (1995), p .521

xxvii Letter from Alice Hargreaves to Miss Dodgson (presumed to be Menella), DFC D/1/18

xxviii Letter from F. Menella Dodgson to Charles Hassard Wilfrid Dodgson, DFC / F / 5/ 13

${ }^{x x i x}$ Anon, 'Lewis Carroll Centenary', Morning Post (28 January 1932). As Johnston notes, 'throughout Europe devotees of a given author still convene as "Friends of X" in order to function as courtly patrons. The Lewis Carroll Society in the UK, and its North American counterpart, play a similar role today. See Johnston, Celebrations, p.86, and Brooker, Alice's Adventures, pp.265-306 
${ }^{x x x}$ David Lowenthal, The Past is A Foreign Country (Cambridge: Cambridge University Press, 1985), p.9. This tendency had been manifest in the Victorian period: 'the Middle Ages are to me the only ages', Ruskin had declared. See Lowenthal, pp.96-98

${ }^{x x x i}$ Mrs Rose L. Wood, 'Alice through the Looking-Glass', letter in The Times (15 February 1932)

xxxii G.B.H., 'A Girl's Memories of Lewis Carroll', letter in The Rochdale Observer (23 April 1932)

xxxiii Anon ('A Guildford Correspondent'), 'Lewis Carroll', letter in Surrey Advertiser (6 February 1932).

Gentlemen were also involved in this process of recollection, though their stories of train journeys are from later in the century, and they are adult witnesses rather than child-friends. Mr S. J. B. Fletcher, for instance, recalls an occasion 'somewhere in the middle nineties' when he met Carroll. Letter to The Times (13 January 1932)

xxxiv Anon, 'Lewis Carroll's Secret', The Daily Mail (27 January 1932)

xxxv Johnston, Celebrations, p.99

${ }^{x x x v i}$ Anon, 'Memorial to Lewis Carroll', The Surrey Times (27 May 1933). The unveiling of the plaque, though it took place the following year, was inspired by, funded by and can be considered part of the centenary events. xxxvii Anon ('J.O.') 'The Art of Nonsense', Birmingham Post (27 January 1932)

xxxviii Anon, 'County Town Topics: “Lewis Carroll” Memorial Hall - Why Not?', Surrey Weekly Press (no date, presumably 31 April 1932), attached to a letter from Leonard Biddle to Miss Dodgson (dated 7 May 1932), asking her to support the campaign for a Memorial Hall and enclosing last week's newspaper, DFC F 5/6 ${ }^{x x x i x}$ Nicola J. Watson, The Literary Tourist: Readers and Places in Romantic \& Victorian Britain (Palgrave Macmillan, 2006), p.5

${ }^{x \mid}$ Watson notes the close relationship between literary tourism and cultural nationalism. Ibid., p.14

xli Johnston, Celebrations, p.23, italics mine

xlii Lord Crewe is described in the article as 'one of the three survivors of Victoria's Cabinet', and himself serves explicitly as a living connection to history.

xliii Light, Forever England, p.8

xliv Light describes the latter approach as 'the last look round' or 'the long weekend' before the war. Ibid., p.9

${ }^{x l v}$ Anon, 'Tribute to Lewis Carroll', Evening Standard (no date)

${ }^{x}$ Avi A letter from F. Menella Dodgson fixes the dates (August-November 1868) and notes that she left Guildford herself in 1930. Anon, 'The Centenary of Lewis Carroll', Surrey Advertiser and County Times (30 January 1932)

xlvii Anon, 'Lewis Carroll Centenary', Guildford City Outlook (June 1932)

xlviii Watson, The Literary Tourist, p.29

${ }^{x l i x}$ Anon, 'Lewis Carroll Centenary', Surrey Advertiser and County Times (23 January 1932)

'Anon, 'Tribute to Lewis Carroll', Evening Standard, op.cit.

li Anon, 'Among the Immortals,' Surrey Times (27 May 1933)

lii Anon, 'Memorial to Lewis Carroll', The Surrey Times, op.cit.

liii Anon, 'Lewis Carroll Centenary', Surrey Advertiser and County Times, op.cit.

liv Watson, The Literary Tourist, p.57

Iv Anon, 'The Lewis Carroll Centenary', Oxford Times (22 January 1932)

Ivi Watson, The Literary Tourist, p.207

Ivii Anon, 'Blemish on Centenary Honours', Daily Express (22 January 1932)

Iviii Anon, 'The Centenary of Lewis Carroll', Surrey Advertiser and County Times.

lix Anon, 'County Town Topics: “Lewis Carroll” Memorial Hall - Why Not?'.

'x See David Rose, 'Will The Lewis Carroll Plaque Be Reinstated?', The Guildford Dragon News, http://www.guildford-dragon.com/2012/02/27/will-the-lewis-carroll-plaque-be-reinstated/ (accessed 22 May 2015)

Ixi Anon, 'Alice in Wonderland Was A Hampshire Lady', Hampshire Advertiser and Independent (30 January 1932)

Ixii Anon, 'Lewis Carroll and Hull', Leeds Mercury (25 January 1932)

Ixiii Anon, 'Creator of the Immortal Alice', Bristol Times and Mirror (27 January 1932)

Ixiv See Walter De La Mare, Lewis Carroll (London: Faber \& Faber Ltd 1932), p.7; De La Mare notes that 'the Victorian age was rich in [literary] exotics. It amuses us moderns, having dried and discoloured them, to make little herbariums of them.'

Ixv Anon, 'Miscellany: Lewis Carroll', Manchester Guardian (27 January 1932). A short piece published the same day notes wryly that if Carroll had written Alice in Wonderland in 1932, it would be taken as plagiarism of Government White Papers and Licensing Commissions. Anon, 'Malice in Blunderland', Morning Post (27 January 1932). Another sadly observes that if other nations could all see the appeal of Alice and Lear, 'there 
would be no need of Disarmament Conferences'. Anon, 'Lewis Carroll and Edward Lear Compared', Birmingham Post (27 January 1932)

Ixvi M.K. 'It's all Nonsense: Lewis Carroll and Alice', Church Times (29 January 1932)

Ixvii ‘Urbanus', 'Round-About Papers', Church Times (January 1932)

Ixviii Light, Forever England, p.2

Ixix Langford Reed, 'Lewis Carroll Centenary', Sunday Times.

${ }^{1 \times x}$ Anon, 'Blemish on Centenary Honours', Daily Express.

Ixxi Anon, 'Lewis Carroll Centenary', Surrey Advertiser and County Times

Ixxii Anon, 'Lewis Carroll Centenary', Morning Post.

Ixxiii Anon, 'Among the Immortals,' Surrey Times.

${ }^{\text {Ixxiv }}$ Anon, 'Memorial to Lewis Carroll', The Surrey Times.

${ }^{1 \times x v}$ Sidney H. Williams and Falconer Madan, 'To Lovers of Alice', letter in The Times.

lxxvi Appeal leaflet with donation form and envelope, DFC F/4/1-3

Ixxvii Anon, 'A Gentle Lover of Childhood', Yorkshire Evening Post (27 January 1932)

Ixxviii See Brooker, Alice's Adventures, p.55. The authors were Will Self and Waldemar Januszczak

Ixxix Lowenthal, The Past is A Foreign Country, pp.16-17

Ixxx See Brooker, Alice's Adventures, p.vii. Thomas notes that Hugh Kingsmill's The Table of Truth (1933) went further, asking whether Carroll saw Alice as 'a girl of thirteen or so, as that age when.....budding breasts and limbs shaping to roundness take on, as it were, the entrancing curves of womanhood...' See Thomas, Lewis Carroll, p.360

Ixxi William Empson, 'Alice in Wonderland: The Child as Swain' in Some Versions of Pastoral (London: Chatto \& Windus, 1935), p.203

Ixxxii Anon, 'Lewis Carroll Centenary', Surrey Advertiser and County Times.

Ixxxiii Anon, 'The Christ Church Don Who Wrote "Alice in Wonderland"', Guildford Mail (26 January 1932)

Ixxxiv A. L Taylor, The White Knight (Edinburgh: Oliver \& Boyd Ltd, 1952), p.32

${ }^{I x \times x v}$ Hugh Haughton, 'Introduction' in Alice's Adventures in Wonderland and Through the Looking-Glass

(London: Penguin, 1998), p.xix 